\title{
PEMANTAUAN KUALITAS AIR DI BAGIAN HULU SUNGAI CISADANE DENGAN INDIKATOR MAKROINVERTEBRATA
}

\author{
Poltak BP. Panjaitan ${ }^{1}$, Supriyono Eko Wardoyo ${ }^{2}$ dan Sofian Rodiana* \\ ${ }^{1}$ Program Studi Kehutanan, ${ }^{2}$ Peminatan Manajemen Hutan \\ Universitas Nusa Bangsa \\ Jalan Baru Km 4 Cimanggu, Tanah Sareal, Bogor 16166 \\ Telp (0251) 8340217, 7535605, 7538760 Fax. (0251)7535605, \\ e-mail : nusabangsa@unb.ac.id
}

\author{
ABSTRACT \\ Observation on the Water Quality of Cisadane River \\ in the Upstream Part Using Macroinvertebrates as The Indikator \\ By. Poltak BP. Panjaitan, Supriyono Eko Wardoyo and Sofian Rodiana
}

\begin{abstract}
Water is an important thing for either human life or other creatures on the earth. Water posses a lot of necesities, among of them is to fullfill domestics, industries, and agriculture. For this purposes people often take from rivers. River Cisedane is one of rivers that available in Bogor City, having water catchment area of $1100 \mathrm{~km} 2$ and is one of main rivers in West Java and Banten Province. One procedure for testing water quality of rivers is to see the invertebrate animals available in the river, because some species are very sensitive for pollution. There were three points in the reserch area that were in upperpart area was Rancamaya, middle area was Pasir Jaya, and the lower area was Situ Gede. Water quality value index in Rancamaya (Upper part) was 5.42, included middle level of water pollution. In Pasir Jaya (middle point) was 4.75, included polluted water level, and in Situ Gede (lower prt) was 4.28 included more pollutud water level. Overall of observed research area were the lower part of river the worse pollution available. The pollution available in the research area was caused by domestics waste from inhabitant and other chemical waste from agriculture.
\end{abstract}

Keyword: Mikroinvertebrata, Cisadane, water quality, upper river part

\begin{abstract}
ABSTRAK
Air merupakan salah satu unsur yang sangat penting bagi kelangsungan hidup manusia maupun mahkluk hidup lainnya yang ada di muka bumi. Air memiliki banyak manfaat, diantaranya untuk memenuhi kebutuhan rumah tangga, industri dan pertanian. Untuk memanfaatkan air tersebut biasanya masyarakat mengambil air dari satu sungai pada suatu Daerah Aliran Sungai (DAS). Salah satu DAS yang terdapat di Kota Bogor yaitu DAS Cisadane dengan daerah tangkapan air seluas $1.100 \mathrm{~km} 2$, selain itu DAS Cisadane merupakan aliran sungai utama di Propinsi Banten dan Jawa Barat. Salah satu cara untuk menilai kualitas air sungai adalah dengan melihat keberadaan makroinvertebrata yang hidup di sungai tersebut. Makroinvertebrata dapat memberikan petunjuk adanya pencemar, karena jenis-jenis tertentu sangat peka terhadap pencemaran. Maka berdasarkan hal tersebut penelitian ini akan mengidentifikasi adanya makroinvertebrata di sungai yang merupakan bioindikator kualitas airnya. Tiga titik pengambilan sampel makro-invertebrata di hulu sungai Cisedane yaitu di bagian atas peneltian (Daerah Rancamaya), di bagian tengah penelitian (Pasir Jaya) dan di bagian bawah penelitian (Situ Gede). Nilai indeks kualitas air di bagian atas penelitian, yaitu di daerah Desa Rancamaya adalah 5,42. Itu menunjukan bahwa kualitas air di daerah tersebut masuk air berpolusi sedang. Pada lokasi penelitian di bagian tengah, yaitu Daerah Desa Pasir Jaya indeks kualitas air nya adalah 4,75. Itu menunjukan bahwa kualitas air di sana masuk air kotor. Sedangkan di bagian bawah penelitian, yaitu daerah Desa Situ Gede indeks kualitas air nya adalah 4,28. Itu menunjukan bahwa kualitas air di sana masuk air kotor. Dari Nilai Indeks Kualitas air di seluruh lokasi hulu sungai penelitian menunjukan bahwa semakin ke bawah kualitas air sungai semakin kotor. Kualitas air di sana diduga diakibatkan oleh sampah atau limbah organik yang berasal dari rumah tangga. Selain itu, kualitas air di sana diduga disebabkan oleh bahan -bahan kimia berbahaya yang berasal dari penggunaan pupuk, pestisida di areal pertanian.
\end{abstract}

Kata kunci : Mikroinvertebrata, Cisadane, kualitas air, hulu.

\section{PENDAHULUAN}

Air merupakan salah satu unsur yang sangat penting bagi kelangsungan hidup manusia maupun mahkluk hidup lainnya yang ada di muka bumi. Air memiliki banyak manfaat, diantaranya untuk memenuhi kebutuhan rumah tangga, industri dan pertanian. Untuk memanfaatkan air tersebut biasanya masyarakat mengambil air dari sungai sungai pada suatu Daerah Aliran Sungai (DAS).
Salah satu DAS yang terdapat di Kota Bogor yaitu DAS Cisadane dengan daerah tangkapan air seluas $1.100 \mathrm{~km} 2$, selain itu DAS Cisadane merupakan aliran sungai utama di Propinsi Banten dan Jawa Barat

Sungai Cisadane diandalkan untuk memenuhi kebutuhan air bagi industri, irigasi dan kebutuhan sehari-hari oleh masyarakat di sekitarnya, diantaranya untuk minum, mandi, masak, pengairan sawah, sehingga kualitas airnya 
perlu dipertahankan. Terutama sungai di daerah hulu, apabila kualitas air sungai di daerah hulu buruk maka bisa dipastikan untuk kualitas air di daerah tengah dan hilir pun akan lebih buruk. Salah satu cara menilai kualitas air sungai adalah dengan melihat keberadaan makroinvertebrata yang hidup di sungai tersebut.

Makroinvertebrata dapat memberikan petunjuk adanya bahan pencemar, karena jenis-jenis tertentu sangat peka terhadap pencemaran. Hal ini dikemukakan oleh Purwati dan Sutapa (1999); Trihardiningrum dan Tjondronegoro (1998) bahwa pengukuran makro-invertebrata dapat memberikan informasi penting tentang kualitas air sungai ssaaat itu dan yang untuk masa datang. Menurut Rahayu, at. al., 2009, makro-invertebrata air memiliki sifatsifat sebagai berikut :

1) Sangat peka terhadap perubahan kualitas air tempat hidupnya, sehingga akan dipengaruhi komposisi dan kelimpahannya

2) Ditemukan hampir di semua perairan

3) Jenisnya cukup banyak dan memberikan respon yang berbeda akibat gangguan yang berbeda

4) Pergerakannya terbatas, sehingga dapat sebagai penunjuk keadaan lingkungan setempat

5) Mudah dikumpulkan dan diidentifikasi paling tidak sampai tingkat family

6) Pengambilan contoh mudah dilakukan, karena memerlukan peralatan sederhana, murah dan tidak berpengaruh terhadap makhluk hidup lainnya.

Maka berdasarkan hal tersebut penelitian kualitas air di bagian hulu daerah aliran sungai Cisadane akan mengidentifikasi makroinvertebrata yang merupakan salah satu bioindikator kualitas air. Makroinvertebrata adalah kelompok hewan yang tidak memiliki tulang belakang dan mudah dilihat dengan kasat mata (ukuran tubuh lebih dari $0.5 \mathrm{~cm}$ ) (Bounchard, M. 2004). Sedangkan metode pemantauan kualitas air secara biologis memiliki kelemahan sebagai berikut (Rahayu , at. al., 2009) :

1. Tidak dapat mengidentifikasi penyebab perubahan yang terjadi

2. Hasil pendugaan menunjukkan kualitas air secara ekologi tetapi tidak dapat menunjukkan adanya bahan patogen atau organism penyebabnya

3. Hanya dapat dilakukan oleh orang yang mengerti tentang biologi perairan ataupun orang yang telah dilatih, karena harus mengidentifikasi secara taksonomi kelompokkelompok organisme petunjuk.
Kelebihan dari metode pemantauan kualitas air secara biologis yaitu :

1. Biaya yang digunakan relatif lebih rendah

2. Cara yang digunakan relatif lebih mudah.

3. Dapat digunakan dalam pendugaan kualitas air karena dapat mencerminkan pengaruh perubahan kondisi fisik dan kimia yang terjadi di perairan dalam selang waktu tertentu.

Tujuan dari penelitian ini adalah mengetahui kualitas air sungai di bagian hulu Sungai Cisadane Kota Bogor secara biologis dengan indikator makroinvertebrata.

\section{METODE PENELITIAN}

Lokasi penelitian dilaksanakan di bagian hulu Sungai Cisadane Kota Bogor. Terletak pada $106^{\circ} 28^{\prime} 50^{\prime \prime}$ - 106 $56^{\prime} 20^{\prime \prime}$ BT dan 6 $0^{\circ} 59^{\prime \prime}$ $6^{\circ} 47^{\prime} 02^{\prime \prime}$ LS. Penelitian ini dilaksanakan pada Pertengahan Juni - Pertengahan Juli 2010.

Alat yang digunakan dalam penelitian adalah jaring/saringan (dengan ukuran mesh 500 $\mu \mathrm{m})$, loup/kaca pembesar, baskom, gelas plastik putih, kamera digital, seperangkat alat tulis dan panduan identifikasi makro-invertebrata air sungai.

Penelitian hanya mengidenti-fikasi kualitas air di bagian hulu sungai Cisadane, Kota Bogor, secara biologi yaitu dengan menggunakan indikator makro-invertebrata yang dilakukan pada waktu banyak hujan.

Pemilihan lokasi pengambilan sampel dilakukan dengan cara purposive sampling. Yaitu dengan membuat dua titik pengambilan sampel di setiap lokasi dengan ukuran 5 m x 2 m (Gambar 1).

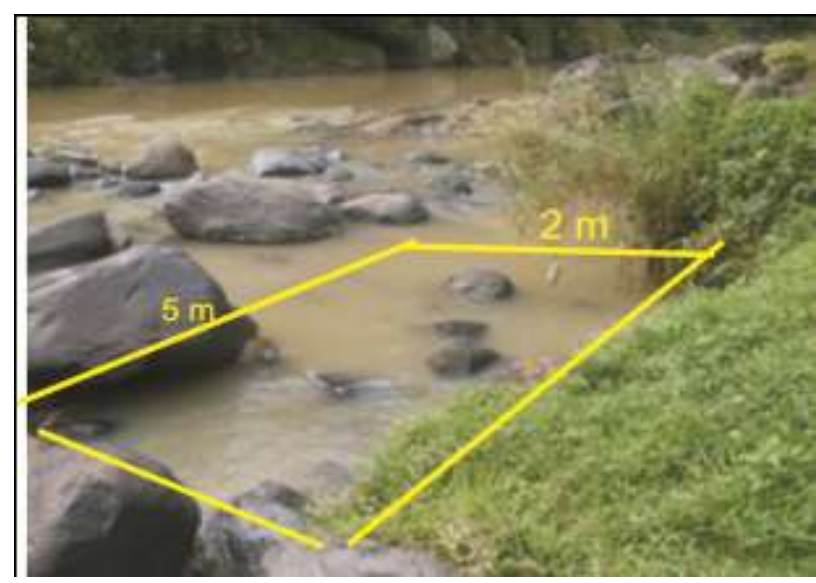

Gambar 1. Plot Pengambilan Sampel 
Lokasi pengambilan sampel yaitu :

1. Di daerah Desa Rancamaya, Kecamatan Bogor Selatan (Bagian atas penelitian)

2. Di daerah Desa Pasir Jaya, Kecamatan Bogor Selatan (Bagian tengah penelitian)

3. Di daerah Desa Situ Gede, Kecamatan Bogor Barat (Bagian bawah penelitian)

Untuk kontrol pengambilan sampel dilakukan di tempat yang diperkirakan belum mengalami pencemaran di Sungai Cisadane, yaitu Desa Srogol, Kecamatan Cijeruk, Kabupaten Bogor (Lebih atas dari lakasi-lokasi sampel no.1, 2, dan 3)

Langkah pengambilan sampel menurut Wetland-International, Indonesia Programme (1996) dan Rahayu, at. al. (2009).

1) Pengambilan sampel dilakukan pada pagi hari saat tidak hujan di tempat yang sudah ditentukan dan saringan dipasang berlawanan arah dengan aliran sungai.

2) Memeriksa keberadaan makro invertebrata pada dasar sungai, dinding sungai, yang menjorok ke dalam batu-batuan, rantingranting dan akar-akar yang ada di dinding sungai, serta makroinvertebrata yang bergerak di atas permukaan air.

3) Menggerakan batu-batu kecil yang ada di badan sungai, ranting - ranting dan akar tumbuhan yang menggantung di tebing sungai.

4) Menempatkan jaring berlawanan aliran air yang dasarnya telah diaduk pada substrat bebatuan, tempatkan jaring pada tempat yang mudah dijangkau dan diambil contoh invertebrata lebih banyak.

5) Mengembalikan ke sungai apabila ditemukan jenis hewan lain masuk ke jaring seperti ikan dan kepiting, karena hewan yang diamati hanya kelompok makroinvertebrata saja.

6) Memasukkan contoh yang diambil dari jaring ke dalam baskom, pastikan baskom telah terdapat air sungai yang cukup untuk menampung hasil yang telah diambil.

7) Sampel dan substrat yang telah diambil diperhatikan dengan seksama adanya sesuatu yang bergerak-gerak.

8) Memindahkan satu binatang ke dalam mangkuk plastik kecil berwarna putih.

9) Lalu mengamati dengan menggunakan kaca pembesar (loup).

10) Mencocokan bentuk binatang menggunakan panduan identifikasi makroinvertebrata sungai untuk mendapatkan nama binatang tersebut.
Pengolahan data dalam penelitian ini dilakukan secara deskriptif yaitu data yang ada diklasifikasikan sehingga diperoleh informasi mengenai kualitas air hulu sungai Cisedane.

Kelompok organisme tersebut dapat bersifat bentik, perifitik, atau berenang bebas. Biota bentik umumnya hidup pada dasar perairan; perifitik hidup pada permukaan tumbuhan, tongkat, batu, atau substrat lain yang berada di dalam air (Wisnu. 2006). Menurut Cairns \& Dickson, ed. (1973) biota aquatik yang dapat digunakan sebagai tolok ukur kualitas lingkungan atas dasar nilai kualitas hayati dan keanekaragaman hayati hendaknya memiliki ciri - ciri sebagai berikut :

1) Harus memiliki kepekaan terhadap perubahan lingkungan perairan dan responnya cepat.

2) Memiliki daur hidup yang kompleks sepanjang tahun atau lebih dan apabila kondisi lingkungan melebihi batas toleransinya biota tersebut akan mati.

3) Hidup sesil (bentik).

4) Tidak mudah/cepat bermigrasi.

Setelah mengamati masing - masing makroinvertebrata dan menjumlahkan skor dari setiap yang ditemukan dengan panduan identifikasi makroinvertebrata kemudian dicari nilai Indek Kualitas Air menggunakan rumus di bawah ini : (Wetland International, Indonesia Programme, 1996).

Indeks Kualitas Air (IKA) $=\frac{\text { Jumlah skor stiapjenis binatang }}{\text { Jumlah jenis binatang }}$

Kemudian dilakukan pengkajian dengan menggunakan Tabel Indeks Kualitas Air (IKA) untuk mendapatkan hasil kualitas air.

\section{HASIL DAN PEMBAHASAN}

\section{Kualitas Air Di Hulu DAS Cisadane Kota Bogor}

Bagian Hulu DAS Cisadane Kota Bogor di bagi menjadi tiga bagian pada penelitian ini, yaitu :

1. Bagian atas penelitian, di daerah Desa Rancamaya, Kecamatan Bogor Selatan

2. Bagian tengah penelitian, di daerah Desa Pasir Jaya, Kecamatan Bogor Selatan

3. Bagian bawah penelitian, di daerah Desa Situ Gede, Kecamatan Bogor Barat 
1. Jenis Makroinvertebrata di bagian atas Penelitian (Di daerah Desa Rancamaya, Kecamatan Bogor Selatan).

Daerah atas penelitian di dominasi oleh areal pemukiman dan pertanian. Kondisi sungai pada umumnya banyak bebatuan sedang dan besar, lebar sungai $\pm 14 \mathrm{~m}$ dengan kedalaman di tepi sungai $\pm 50 \mathrm{~cm}$. Foto lokasi penelitian dapat dilihat pada Lampiran 2.

Di lokasi penelitian ditemukan tujuh jenis makroinvertebrata. Dapat dilihat pada Tabel 3. Untuk gambar jenis makroinvertebrata dapat dilihat pada Lampiran 2 dan Lampiran 3 untuk foto jenis makroinvertebrata yang ditemukan.

Tabel 1. Penentuan skor pada jenis makroinvertebrata menurut buku panduan pengenalan Invertebrata kolam dan sungai di Asia Tenggara, (Wetland Internasional, Indonesia program, 1996).

\begin{tabular}{|c|c|c|}
\hline No & Nama Binatang & Skor \\
\hline 1 & Cacing bersegmen & 1 \\
\hline 2 & Larva mrutu biasa & 2 \\
\hline 3 & Belatung ekor tikus & 3 \\
\hline 4 & Lintah & 3 \\
\hline 5 & Kepiting sungai & 3 \\
\hline 6 & Kerang & 3 \\
\hline 7 & Siput tanpa pintu & 3 \\
\hline 8 & Nimfa capung jarum ekor tebal & 3 \\
\hline 9 & Nimfa capung Dobson & 4 \\
\hline 10 & Nimfa capung sialid & 4 \\
\hline 11 & Nimfa lalat sehari perenang & 4 \\
\hline 12 & Larva lalat atau nyamuk lainnya & 5 \\
\hline 13 & Cacing pipih & 5 \\
\hline 14 & Larva kumbang & 5 \\
\hline 15 & Kumbang dewasa & 5 \\
\hline 16 & Kepik pejalan kaki & 5 \\
\hline 17 & Anggang - anggang & 5 \\
\hline 18 & Kepik perenang punggung & 5 \\
\hline 19 & Kepik pendayung & 5 \\
\hline 20 & Kepik air lainnya & 5 \\
\hline 21 & Siput berpintu, $\geq 15 \mathrm{~mm}$ & 6 \\
\hline 22 & Kijing & 6 \\
\hline 23 & Limpet air tawar & 6 \\
\hline 24 & Nimfa capung biasa & 6 \\
\hline 25 & Nimfa capung jarum lainnya & 6 \\
\hline 26 & Larva ulat air (tanpa kantung) & 7 \\
\hline 27 & Larva ulat kantung air (kantung terbuat dari dedaunan) & 7 \\
\hline 28 & Nimfa lalat sehari (Insang segi empat) & 7 \\
\hline 29 & Udang air tawar dan udang biasa & 8 \\
\hline 30 & Kepik pinggan bermoncong panjang & 10 \\
\hline 31 & Larva ulat kantung air (kantung terbuat dari pasir atau kerikil) & 10 \\
\hline 32 & Nimfa lalat sehari pipih & 10 \\
\hline 33 & Nimfa lalat sehari insang bercabang & 10 \\
\hline 34 & Nimfa lalat sehari penggali & 10 \\
\hline 35 & Nimfa plekoptera & 10 \\
\hline
\end{tabular}


Tabel 2. Indeks Kualitas Air

\begin{tabular}{|c|c|}
\hline \multicolumn{2}{|c|}{ INDEKS KUALITAS AIR } \\
\hline SKOR & KUALITAS AIR \\
\hline 0 & Luar biasa kotor \\
\hline $1.0-2.9$ & Sangat kotor \\
\hline $3.0-4.9$ & Kotor \\
\hline $5.0-5.9$ & Sedang (rata-rata) \\
\hline $6.0-7.9$ & Agak bersih sampai bersih \\
\hline $8.0-10.0$ & Sangat bersih \\
\hline
\end{tabular}

(Sumber: Wetland International Indonesia Programme, 1996 ).

Tabel 3. Jenis Makroinvertebrata dan Skor di Daerah Desa Rancamaya, Kecamatan Bogor Selatan.

\begin{tabular}{clc}
\hline No & \multicolumn{1}{c}{ Jenis Makroinvertebrata } & Skor \\
\hline 1 & Nimfa capung biasa berekor dua & 4 \\
2 & Nimfa lalat sehari insang bercabang & 4 \\
3 & Engkang - engkang & 5 \\
4 & Kepik Pendayung & 5 \\
5 & Kepik Pejalan kaki bahu lebar & 5 \\
6 & Kumbang putar & 5 \\
7 & Nimfa Plekoptera $\quad$ Total & 10 \\
\hline & & 38 \\
\hline
\end{tabular}

$$
\begin{aligned}
\text { Indeks Kualitas Air ( IKA ) A } & =\frac{\text { Jumlah skor setiap jenis binatang }}{\text { Jumlah jenis binatang }} \\
\text { Indeks Kualitas Air ( IKA ) A } & =\frac{38}{7} \\
& =5,42
\end{aligned}
$$

Nilai 5,42, menurut buku panduan pengenalan invertebrata kolam dan sungai di Asia Tenggara, (Wetland Internasional, Ind program 1996) termasuk dalam kategori kualitas air sedang. Air dengan kualitas sedang diduga dapat digunakan untuk minum setelah melalui proses pengolahan, dapat digunakan untuk kegiatan pertanian, misalnya untuk irigasi, untuk kegiatan peternakan, misalnya untuk minum dan memandikan hewan ternak dan kegiatan industri

Klasifikasi dan kriteria kualitas air di Indonesia diatur dalam Peraturan Pemerintah No. 82 Tahun 2001. Berdasarkan Peraturan Pemerintah tersebut, kualitas air diklasifikasikan menjadi empat kelas yaitu :

1. Kelas I : dapat digunakan sebagai air minum atau untuk keperluan konsumsi lainnya

2. Kelas II : dapat digunakan untuk prasarana/sarana rekreasi air, pembudidayaan ikan air tawar, peternakan dan mengairi tanaman

3. Kelas III : dapat digunakan untuk pembudidayaan ikan air tawar, peternakan dan mengairi tanaman

4. Kelas IV : dapat digunakan untuk mengairi tanaman

\section{Jenis Makroinvertebrata di bagian tengah penelitian (Daerah Desa Pasir Jaya, Kecamatan Bogor Selatan)}

Daerah tengah penelitian termasuk areal pemukiman yang padat. Kondisi sungai pada umumnya berjenis substrat bebatuan sedang dan besar, bantaran sungai sempit dan tinggi. Lebar sungai $\pm 14 \mathrm{~m}$. Di lokasi ini cukup banyak sampah, terutama sampah rumah tangga dan plastik. Foto lokasi penelitian dapat dilihat pada Lampiran 1. Di lokasi penelitian ditemukan empat jenis makroinvertebrata. Dapat di lihat pada Tabel 4. 

Tabel 4. Jenis Makroinvertebrata dan Skor di Daerah Desa Pasir Jaya, Kecamatan Bogor Selatan.

\begin{tabular}{clc}
\hline No & \multicolumn{1}{c}{ Jenis Makroinvertebrata } & Skor \\
\hline 1 & Kepiting sungai & 3 \\
2 & Engkang - engkang & 5 \\
3 & Kepik pejalan kaki bahu lebar & 5 \\
4 & Nimfa capung jarum biasa & 6 \\
\hline \multicolumn{2}{r}{ Total } & 19 \\
\hline
\end{tabular}

Indeks Kualitas Air ( IKA ) B $=\frac{\text { Jumlah skor setiap jenis binatang }}{\text { Jenis binatang }}$

Indeks Kualitas Air ( IKA ) B $=\frac{19}{4}$

$=4,75$

3. Jenis Makroinvertebrata di bagian bawah penelitian (Daerah Desa Situ Gede, Kecamatan Bogor Barat)

Daerah penelitian adalah areal pemukiman dan pertanian. Kondisi sungai pada umumnya berjenis substrat batu dan lumpur, bantaran sungai landai dan lebar, lebar sungai \pm 13 $\mathrm{m}$ dengan kedalaman tepi sungai $\pm 50 \mathrm{~cm}$. Foto lokasi penelitian dapat dilihat pada Lampiran 1. Di lokasi pengambilan sampel ditemukan tujuh jenis makroinvertebrata. Dapat di lihat pada Tabel 5. Untuk gambar jenis makroinvertebrata yang ditemukan dapat dilihat pada Lampiran 2 dan Lampiran 3 untuk foto jenis makroinvertebrata yang ditemukan.

Nilai 4,75 menurut buku panduan pengenalan invertebrata kolam dan sungai di Asia Tenggara, (Wetland Internasional, Ind program,1996) termasuk dalam kategori kualitas air kotor. Air dengan kualitas kotor dapat memungkinkan untuk minum setelah melalui proses pengolahan, dapat digunakan untuk kegiatan pertanian, misalnya untuk irigasi, untuk kegiatan peternakan, misalnya untuk minum dan memandikan hewan ternak dan kegiatan industri, misalnya sebagai pendingin mesin.

Nilai 4,28, menurut buku panduan pengenalan invertebrata kolam dan sungai di Asia Tenggara, (Wetland Int, Ind program, 1996) termasuk dalam kategori kualitas air kotor. Air dengan kualitas kotor masih memungkinkan digunakan untuk minum setelah melalui proses pengolahan tertentu, dapat digunakan untuk kegiatan pertanian, misalnya untuk irigasi, untuk kegiatan peternakan, misalnya untuk minum dan memandikan hewan ternak dan kegiatan industri, misalnya untuk pendingin mesin.

Tabel 5. Jenis Makroinvertebrata dan Skor di Daerah Desa Situ Gede, Kecamatan Bogor Selatan.

\begin{tabular}{|c|c|c|}
\hline No & Jenis Makroinvertebrata & Skor \\
\hline 1 & Cacing air & 1 \\
\hline 2 & Kepiting sungai & 3 \\
\hline 3 & Siput kolam tidak berpintu & 3 \\
\hline 4 & Kepik pejalan kaki bahu lebar & 5 \\
\hline 5 & Larva lalat & 5 \\
\hline 6 & Engkang - engkang & 5 \\
\hline 7 & Udang air tawar & 8 \\
\hline
\end{tabular}

$$
\begin{aligned}
\text { Indeks Kualitas Air ( IKA ) C } & =\frac{\text { Jumlah skor setiap jenis binatang }}{\text { Jumlah jenis binatang }} \\
\text { Indeks Kualitas Air ( IKA ) } \mathrm{C} & =\frac{30}{7} \\
& =4,28 \text { (Termasuk kualitas air kotor) }
\end{aligned}
$$




\section{Kualitas Air di bagian kontrol (hulu) sampling penelitian Sungai Cisadane, Desa Srogol, Kabupaten Bogor.}

Kualitas air di Bagian tersebut, merupakan daerah kontrol untuk lokasi penelitian karena letaknya di atasnya lokasi penelitian atau disekitar sumber mata air. Dari jenis makroinvertebrata yang ditemukan dapat diketahui bahwa Nilai Indeks Kualitas Air di Hulu DAS Cisadane adalah 6, termasuk dalam kategori bersih bila berpedoman pada Paduan Pengenalan Invertebrata Kolam dan Sungai di Asia Tenggara,

Nilai 6, menurut Wetland Int., Ind Program (1996) termasuk dalam kategori kualitas air bersih. Kualitas air bersih sangat memungkinkan untuk dikonsumsi, namun masih perlu suatu pengolahan. Selain itu kualitas air bersih dapat digunakan untuk irigasi dalam bidang pertanian, sebagai konsumsi hewan ternak dan kegiatan industri, misalnya untuk pendingin mesin.

\section{Implikasi Hasil Penelitian}

Daerah Aliran Sungai (DAS) bagian hulu Cisadane Kota Bogor merupakan daerah yang didominasi oleh pemukiman dan pertanian. Menurut Linsley, et al. (1980) Daerah Aliran Sungai (DAS) secara umum didefinisikan sebagai
(Wetland Int, Ind prog, 1996). Kualitas air di sana diduga dipengaruhi oleh jenis penggunaan lahan oleh masyarakat dan jumlah penduduk. Lahan di sana sebagian besar dimanfaatkan oleh masyarakat sebagai lahan pertanian, sedangkan sebagian kecil digunakan untuk pemukiman. Selain itu lahan terbuka hijau masih luas. Foto lokasi penelitian dapat dilihat pada Lampiran 1. Dari hasil identifikasi, terdapat sepuluh jenis makroinvertebrata yang ditemukan. Hasil tersebut dapat dilihat pada Tabel 6. Untuk gambar jenis makroinvertebrata yang ditemukan dapat dilihat pada Lampiran 2.

suatu hamparan wilayah yang dibatasi oleh pembatas topografi berupa punggung bukit yang menerima, mengumpulkan air hujan, sedimen dan unsur hara serta mengalirkannya melalui anak-anak sungai dan keluar pada sungai utama ke laut atau danau. Sedangkan menurut Manan (1977) bahwa DAS adalah suatu wilayah penerima air hujan yang dibatasi oleh punggung bukit atau gunung, dimana semua curah hujan yang jatuh diatasnya akan mengalir di sungai utama dan akhirnya bermuara kelaut. Hal ini diperkirakan apa yang ada di DAS menjadi faktor pemicu kualitas air menjadi kotor. Dari aktifitas rumah tangga yang berupa sampah bahan organik dan bahan-bahan kimia berbahaya yang berasal dari pertanian (penggunaan pupuk, penggunaan pestisida, dll).

Tabel 6. Jenis Makroinvertebrata di bagian kontrol (Hulu) Cisadane, Desa Srogol, Kabupaten Bogor.

\begin{tabular}{clc}
\hline No & \multicolumn{1}{c}{ Jenis Makroinvertebrata } & Skor \\
\hline 1 & Kepiting sungai & 3 \\
2 & Siput kolam tidak berpintu & 3 \\
3 & Kepik pejalan kaki & 5 \\
4 & Kumbang putar & 5 \\
5 & Kepik air & 5 \\
6 & Engkang - engkang & 5 \\
7 & Siput berpintu & 6 \\
8 & Udang air tawar & 8 \\
9 & Larva ulat kantung air & 10 \\
10 & Nimfa lalat sehari pipih & 10 \\
\hline \multicolumn{2}{c}{ Total }
\end{tabular}

$$
\begin{aligned}
\text { Indeks Kualitas Air ( IKA ) B } & =\frac{\text { Jumlah skor setiap jenis binatang }}{\text { jenis binatang }} \\
\text { Indeks Kualitas Air ( IKA ) B } & =\frac{60}{10} \\
& =6
\end{aligned}
$$


Kualitas air dapat diketahui nilainya dengan mengukur peubah fisika, kimia dan biologi. Monitoring kualitas air secara fisik dapat dilakukan dengan mengukur peubah-peubahnya seperti suhu, muatan sedimen, kecepatan aliran, ukuran batuan dasar sungai, turbiditas/ kekeruhan, warna, bau, dan jenis vegetasi di sekitar sungai. Peubah-peubah yang digunakan pada pemantauan fisik merupakan informasi pendukung dalam penentuan kualitas air secara kimia dan biologi. Hingga saat ini, dikenal ada dua jenis pendugaan kualitas air yaitu fisikkimia dan biologi (Rahayu, dkk, 2009).

Sedangkan kualitas air di daerah kontrol (Desa Srogol) yang bersih itu diperkirakan karena jumlah penduduk yang tidak padat dibandingkan penduduk di lokasi sampling dan masih terdapat banyak lahan terbuka hijau. Berikut adalah Tabel 8. Perbandingan total skor dari jenis makroinvertebrata yang ditemukan di daerah penelitian.

Tabel 7. Persyaratan Air Bersih Menurut Peraturan Menteri Kesehatan Republik Indonesia No.173/Men.Kes/Per/VII/1977

Syarat fisik

1. Air harus bersih dan tidak keruh

2. Tidak berwarna apapun

3. Tidak berasa apapun

4. Tidak berbau apapun

5. Suhu antara 10-25 C (sejuk)

6. Tidak meninggalkan endapan
Syarat kimiawi

1. Tidak mengandung bahan kimiawi yang mengandung racun

2. Tidak mengandung zat-zat kimiawi yang berlebihan

3. Cukup yodium

4. $\mathrm{pH}$ air antara $6,5-9,2$

Tabel 8. Perbandingan total skor dan Nilai Indeks Kualitas Air jenis makroinvertebrata yang ditemukan di daerah penelitian.

\begin{tabular}{llcccc}
\hline No & \multicolumn{1}{c}{ Jenis Makroinvertebrata } & Atas & Tengah & Bawah & Kontrol (teratas) \\
\hline 1 & Cacing air & - & - & 1 & - \\
2 & Kepiting sungai & - & 3 & 3 & 3 \\
3 & Siput kolam tidak berpintu & - & - & 3 & 3 \\
4 & Nimfa capung biasa berekor dua & 4 & - & - & - \\
5 & Kepik pejalan kaki bahu lebar & 5 & 5 & 5 & 5 \\
6 & Kumbang putar & 5 & - & - & 5 \\
7 & Kepik pendayung & 5 & - & - & 5 \\
8 & Engkang - engkang & 5 & 5 & 5 & 5 \\
9 & Larva lalat & - & - & 5 & - \\
10 & Nimfa capung jarum biasa & - & 6 & - & - \\
11 & Siput berpintu & - & - & - & 6 \\
12 & Nimfa lalat sehari insang segi empat & 7 & - & - & - \\
13 & Udang air tawar & - & - & 8 & 8 \\
14 & Larva ulat kantung air & - & - & - & 10 \\
15 & Nimfa lalat sehari pipih & - & - & - & 60 \\
\hline$\quad \quad$ Total & 31 & 19 & 30 & 6 \\
\hline
\end{tabular}


Dari perbandingan tabel di atas dapat di lihat bahwa kepik pejalan kaki bahu lebar dan engkang - engkang merupakan jenis makroinvertebrata yang dominan ditemukan di seluruh bagian lokasi penelitian, itu menandakan bahwa jenis tersebut dapat hidup di lokasi yang kualitas airnya bersih,sedang dan kotor. Selain itu cacing air dari tabel di atas menunjukan bahwa cacing air hidup di kualitas air yang kotor, dan diduga kualitas air yang sangat kotor. Untuk jenis makroinvertebrata Larva ulat kantung air dan Nimfa lalat sehari pipih hanya ditemukan di daerah control, itu menandakan bahwa jenis tersebut dapat ditemukan di lokasi aliran sungai yang memiliki kualitas air bersih.

Penelitian kualitas air sungai di sungai Badung (Denpasar), sungai Babon (Semarang), dan sungai Way Seputih (Lampung) dengan metoda yang sama yaitu menggunakan bio-indikator dengan makro-invertebrata telah dilakukan oleh Purwati dan Sutapa (1999) namun dengan menghitung nilai Saprobic BMWP (Biological Monitoring Water Party's\}, menunjukan bahwa sungai Badung paling banyak gangguan polusi disbanding yang lain.

Penelitian di saluran irigasi waduk Jatiluhur dengan metoda yang sama telah dilakukan oleh Krismono, Kartamihardja, dan Zaenal (2000) menghasilkan bahwa ada pengaruh saringan budidaya ikan di saluran tersebut yang menekan kelimpahan makroinvertebratanya (Moluska, kerang, dan cacing).

\section{KESIMPULAN DAN SARAN}

\section{Kesimpulan}

Nilai indeks kualitas air di bagian hulu penelitian, yaitu di daerah Desa Rancamaya adalah 5,42 . Itu menunjukan bahwa kualitas air di daerah tersebut sedang. Pada lokasi penelitian di bagian tengah, yaitu Daerah Desa Pasir Jaya indeks kualitas air nya adalah 4,75. Itu menunjukan bahwa kualitas air di sana kotor. Sedangkan di lokasi hilir penelitian, yaitu daerah Desa Situ Gede indeks kualitas air nya adalah 4,28. Itu menunjukan bahwa kualitas air di sana kotor. Dari Nilai Indeks Kualitas air di seluruh lokasi penelitian menunjukan bahwa semakin ke hilir kualitas air sungai semakin kotor.

\section{Saran}

1. Pada saat memantau kualitas air sebaiknya kegiatan dilaksanakan secara berkala dan pada musim yang berbeda yaitu pada musim kemarau dan musim hujan. Hal ini untuk mendapatkan hasil yang lebih proporsional.

2. Untuk memudahkan identifikasi sebaiknya digunakan kamera dengan lensa yang memiliki tingkat kejelasan ( pixel) tinggi

3. Untuk memperbaiki kualitas air sungai perlu dilakukan upaya penyadaran kepada masyarakat secara berkala mengenai pendidikan lingkungan.

\section{DAFTAR PUSTAKA}

Bouchard, R. W., Jr. 2004. Guide To Aquatic Makroinvertebrates of The Upper Midwest. Water Resources Center. University OfMinnesota.St.Paul.MN.2008 PP.

Cairns, J. J. and K. L. Dickson, ed. 1973. Biological Methods for the Assess- ment of Water Quality, 4S7'M Special Technical publication 528; Ameri-can Soc. for Testing and Material.

Krismono, E. S. Kartamihardja, dan S. Zaenal, 2000. Pengaruh saringan budidaya ikan (Sariban) di saluran terhadap komunitas benthos. Jurnal Penelitian Perikanan Indonesia vol. 6 no. $2: 33-42$.

Linsley, R. K., et al., 1980. Applied Hydrology. New Delhi: Tata McGraw Hill Publication. Co.

Manan, 1977. Pengaruh Hutan dan Manajemen Daerah Aliran Sungai. Skripsi. Departemen Manajemen Hutan Fakultas Kehutanan IPB. Bogor.

Peraturan Pemerintah Republik Indonesia No. 82 2001. Pengelolaan Kualitas Air dan Pengendalian Pencemaran Air. Dinas Lingkungan Hidup : Jakarta.

Peraturan Menteri Kesehatan Republik Indonesia No. 173 1977. Penyediaan air bersih yang layak untuk dikonsumsi oleh masyarakat. Departemen Kesehatan RI : Jakarta.

Purwati, U. S. dan I Sutapa, 1999. Keanekaragaman Hayati Mikrobiota Di Beberapa Sungai Prokasih. Jurnal Studi Pembangunan, Lingkungan \& Kemasyarakatan; Tahun I/1999; No. 3; 12 24 : Jakarta 
Rahayu S, Widodo RH, Van Noordwijk M, Suryadi I dan Verbist B. 2009. Monitoring air di daerah aliran sungai. Bogor, Indonesia. World Agroforestry Centre - Southeast AsiaRegional Office. $104 \mathrm{p}$.

Wetland Int, Ind prog., 1996. Panduan Pengenalan Invertebrata Kolam dan Sungai Di Asia Tenggara. Santi Susanti ( Adaptor) di dukung oleh The British Freshwater Name Trail ), Bogor.
Trihadiningrum. Y \& I. Tjondronegoro. 1998. Makroinvertebrata Sebagai Bioindikator Pencemaran Badan Air Tawar Di Indonesia Jurnal Lingkungan dan Pembangunan. 18 (1) : $45-60$.

Wisnu, W., 2006. Metode Prakiraan Dampak dan Pengelolaannya pada Komponen Biota akuatik. Skripsi. Pusat Penelitian Sumber Daya Manusia dan Lingkungan. Universitas Indonesia : Depok. 


\section{Lampiran 1. Gambar Lokasi Penelitian}

\section{A. Gambar bagian atas penelitian (Daerah} Rancamaya, Bogor Selatan )

Pengambilan sampel dilaksanakan pada hari Minggu, 27 Juni 2010 pukul $12.30-14.30$ WIB dan 18 Juli 2010 pukul $09.40-10.30$ WIB. Daerah pengambilan sampel di dominasi oleh areal pemukiman dan pertanian. Kondisi sungai pada umumnya banyak bebatuan sedang dan besar, Lebar sungai $\pm 15 \mathrm{~m}$ dengan kedalaman di tepi sungai $\pm 50 \mathrm{~cm}$.

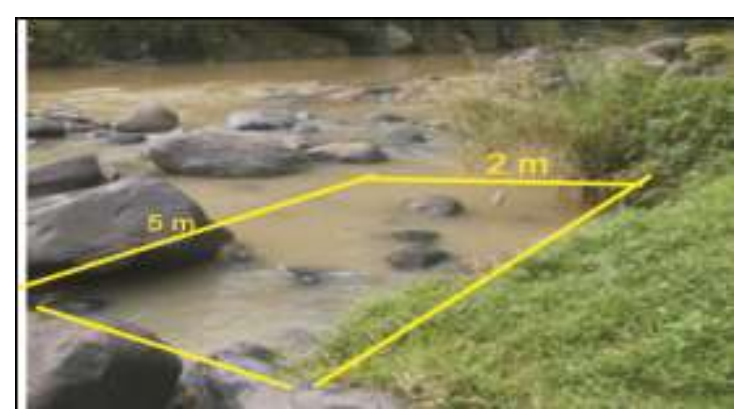

Gambar bagian atas penelitian

B. Gambar bagian tengah penelitian (Daerah Desa Pasir Jaya, Kecamatan Bogor Selatan)

Pengambilan sampel dilaksanakan pada hari Rabu, 30 Juni 2010 pukul 13.30 - 14.45 WIB dan 18 Juli 2010 pukul 13.40 - 15.00 WIB. Daerah pengambilan sampel termasuk areal pemukiman yang cukup padat.

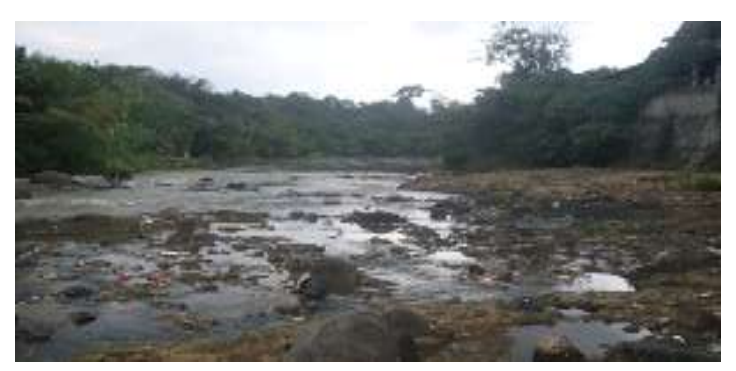

Gambar bagian tengah penelitian

Kondisi sungai pada umumnya berjenis substrat bebatuan sedang dan besar, bantaran sungai sempit dan tinggi. Di lokasi ini cukup banyak sampah, terutama sampah rumah tangga dan plastik

\section{Gambar bagian hilir penelitian (Daerah}

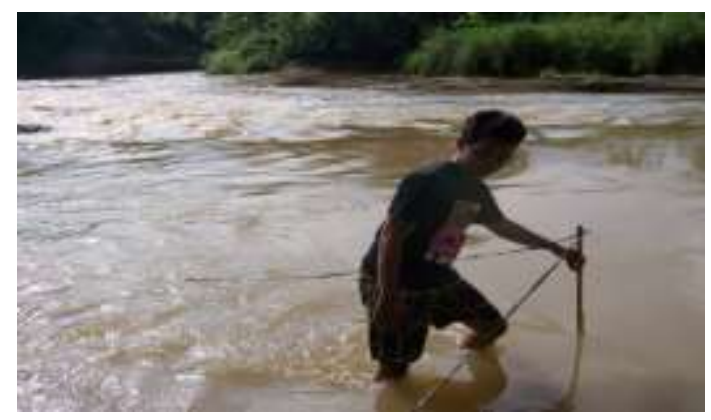

Desa Situ Gede, Kecamatan Bogor Barat).

Pengambilan sampel dilaksanakan pada hari Minggu, 27 Juni 2010 pukul $09.10-10.30$ WIB dan 6 Juli 2010 pukul $10.21-11.40$ WIB. Daerah pengambilan sampel di dominasi areal pemukiman dan pertanian. Kondisi sungai pada umumnya berjenis substrat batu dan lumpur. Bantaran sungai landai dan lebar, lebar sungai $\pm 14 \mathrm{~m}$ dengan kedalaman tepi sungai $\pm 50 \mathrm{~cm}$.

Gambar bagian bawah penelitian

\section{Gambar daerah kontrol (hulu) Daerah Desa Srogol, Kabupaten Bogor}

Pengambilan sampel dilaksanakan pada hari Selasa, 29 Juni 2010 pukul 08.30 - 11.02 WIB dan 4 Juli 2010 pukul 10.21 - 11.40 WIB. Daerah pengambilan sampel di dominasi areal pemukiman dan pertanian. Kondisi sungai pada umumnya berjenis substrat batu dan lumpur. Bantaran sungai landai dan lebar, lebar sungai $\pm 12 \mathrm{~m}$ dengan kedalaman tepi sungai \pm $30 \mathrm{~cm}$.

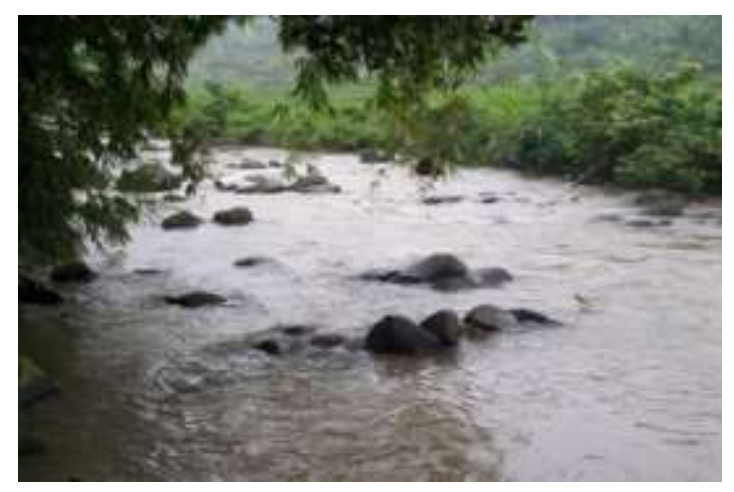

Gambar 8. Gambar daerah kontrol 


\section{Lampiran 2. Gambar Jenis Makroinvertebrata Di Daerah Penelitian (Hulu DAS Cisadane Kota Bogor) dan Daerah Hulu DAS Cisadane.}

A. Jenis Makroinvertebrata di Daerah Desa Rancamaya, Kecamatan Bogor Selatan (Hulu Penelitian).

\begin{tabular}{|c|c|c|}
\hline No & Jenis Makroinvertebrata & Skor \\
\hline 1 & Nimfa capung biasa berekor dua & 4 \\
\hline 2 & Nimfa lalat sehari ins & 4 \\
\hline 3 & Engkang - eng & 5 \\
\hline 4 & Kepik Pendayung & 5 \\
\hline 5 & Kepik pejalan kaki b & 5 \\
\hline 6 & Kumbang Putar & 5 \\
\hline 7 & Nimfa plekoptera & 10 \\
\hline Total & & 38 \\
\hline
\end{tabular}


B. Jenis Makroinvertebrata di Daerah Desa Pasir Jaya, Kecamatan Bogor Selatan (Tengah penelitian).

\begin{tabular}{|c|c|c|}
\hline No & Jenis Makroinvertebrata & Skor \\
\hline 1 & Kepiting sungai & 3 \\
\hline & Engkang - engkang & 5 \\
\hline 3 & Kepik pejalan kaki & 5 \\
\hline 4 & Nimfa capung jar & 6 \\
\hline Total & & 19 \\
\hline
\end{tabular}

C. Jenis Makroinvertebrata di Daerah Desa Situ Gede, Kecamatan Bogor Barat (Hilir penelitian)

\begin{tabular}{|c|c|c|}
\hline No & Jenis Makroinvertebrata & Skor \\
\hline 1 & Cacing air & 1 \\
\hline 2 & Kepiting sungai & 3 \\
\hline 3 & Siput kolam tak berpintu & 3 \\
\hline 4 & Kepik pejalan ka & 5 \\
\hline 5 & Larva lalat & 5 \\
\hline 6 & Engkang - eng & 5 \\
\hline 7 & Udang air tawar & 8 \\
\hline Total & & 30 \\
\hline
\end{tabular}


D. Jenis Makroinvertebrata di Daerah Hulu Cisadane, Desa Srogol, Kabupaten Bogor (Kontrol penelitian ).

\begin{tabular}{|c|c|c|}
\hline No & Jenis Makroinvertebrata & Skor \\
\hline 1 & Kepiting sungai & 3 \\
\hline 2 & Siput kolam tak berpintu & 3 \\
\hline 3 & Engkang - eng & 5 \\
\hline 4 & Kepik Pejalan kaki & 5 \\
\hline 5 & Kumbang Putar & 5 \\
\hline 6 & Kepik Air & 5 \\
\hline 7 & Siput berpintu & 6 \\
\hline 8 & Udang air tawar & 8 \\
\hline 9 & Larva ulat kantung air & 10 \\
\hline 10 & Nimfa lalat sehari pip & 10 \\
\hline Jumlah & & 55 \\
\hline
\end{tabular}




\section{Lampiran 3. Foto makroinvertebrata yang ditemukan di lokasi penelitian}

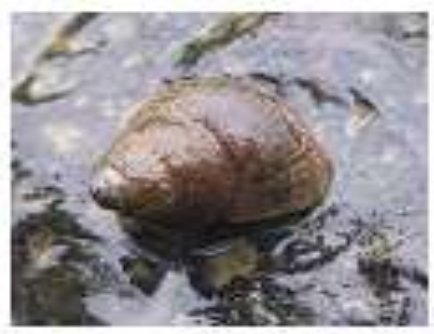

Siput berpintu dan siput tidak berpintu

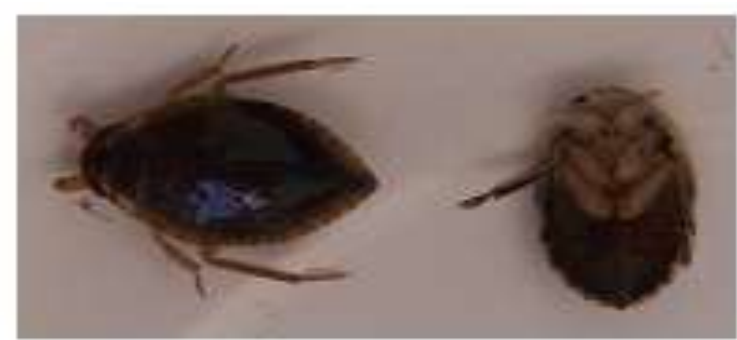

Kepik air

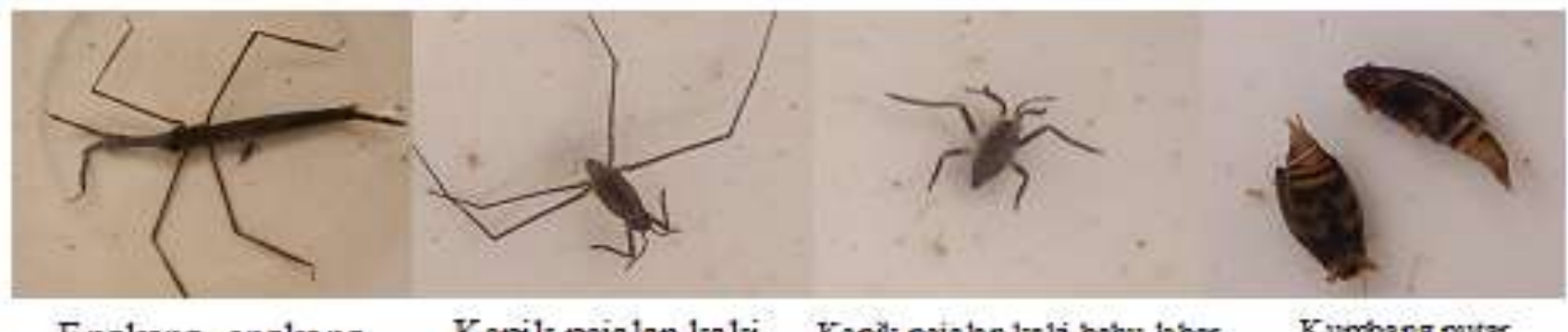

\section{Engkang-engkang Kepik pejalan kaki Kepik pejalankali bahu lebar Kumbang putar}
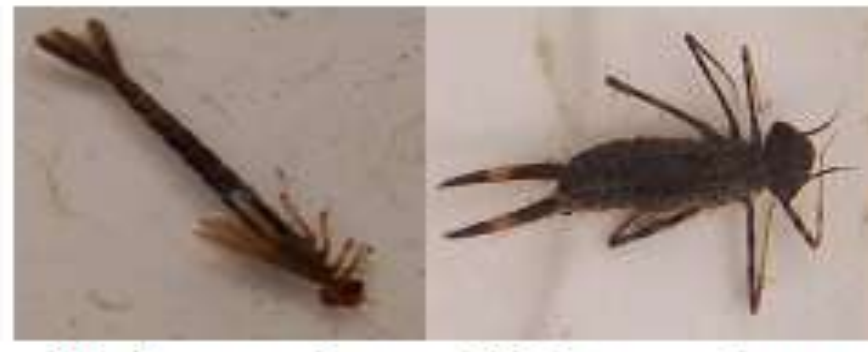

Nimfa capung jarum biasa

Nimfa capung jarum ekor 2

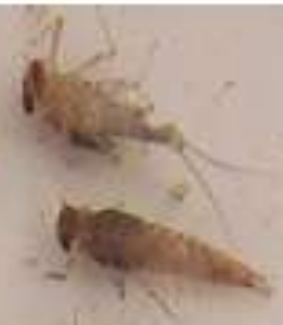

Nimfa Plekoptera

Nimfa lalat sehari perenang

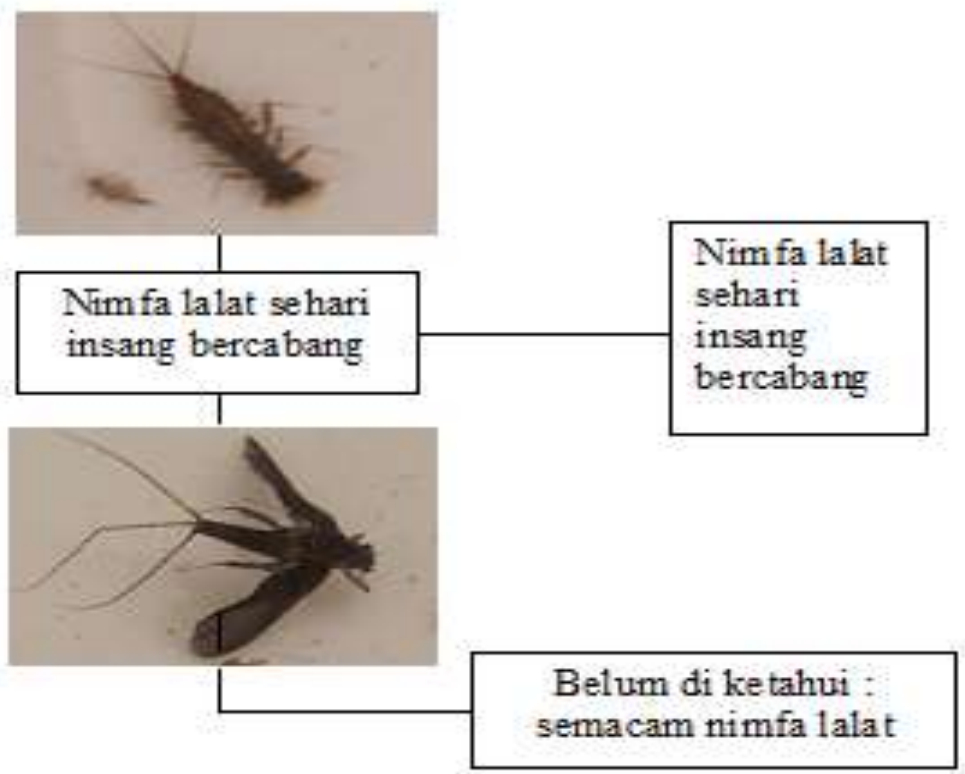

Udang air tawar

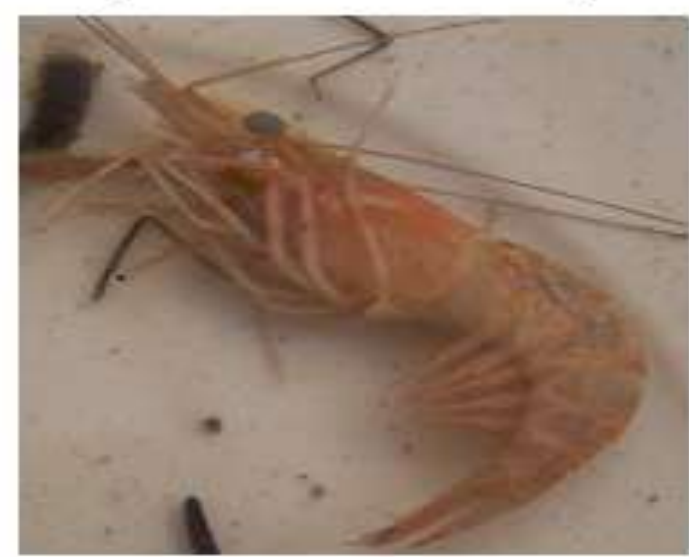

